\title{
First record of a neolampadoid echinoid from the Paleogene of Western Australia
}

\author{
Sarah Martin ${ }^{1}$ and Kenneth J. McNamara ${ }^{2}$ \\ 'Department of Applied Geology, Curtin University of Technology, Bentley, Western Australia 6102, Australia \\ ${ }^{2}$ Department of Earth and Planetary Sciences, Western Australian Museum, \\ Francis Street, Perth, Western Australia 6000, Australia. Email: ken.mcnamara@museum.wa.gov.au
}

\begin{abstract}
A neolampadoid echinoid is described from the Late Eocene Pallinup Limestone, western Eucla Basin. This represents the first record of this order from the Paleogene of the western half of the continent. The echinoid is characterised by the possession of a tetrabasal apical system that has only two gonopores. It shares many similarities with Aphanophora? bassoris Holmes, 1995, from the coeval Kingscote Limestone, Kangaroo Island, South Australia, with which it is questioningly compared. The only record of a living species of Aphanophora found in Australian waters is based on a single neolampadoid collected from northwestern Australia, and tentatively assigned to the genus. The temporal range of this genus in the eastern Indian Ocean region may therefore extend back some 40 million years to the Late Eocene.
\end{abstract}

\section{INTRODUCTION}

Four species of neolampadoid echinoids have been described from the Cenozoic of Australia. The oldest of these are Pisolampas concinna Philip, 1963 and Aphanophora? bassoris Holmes, 1995, both of which been found within late Middle to early Late Eocene units deposited during the Tortachilla Transgression, in the St Vincent Basin in southeastern Australia. The former species was described on the basis of material collected from the Tortachilla Limestone, which outcrops at the southern end of Maslin Bay, South Australia, the latter from the lower beds of the Kingscote Limestone, Kangaroo Island, South Australia. The other two species, found in the St Vincent, Murray and Otway Basins are: Notolampas flosculus Philip, 1963, from the Late Oligocene? to Early Miocene Gambier Limestone, Mannum Formation and Port Willunga Formation in South Australia, and Actapericulum bicarinatum Holmes, 1995, from the Early Miocene Puebla Formation in Victoria, and the Mannum Formation and Gambier Limestone in South Australia (Holmes 1995).

Here we describe a single specimen of a neolampadoid echinoid from the Pallinup Formation in the western Eucla Basin. The specimen represents the first record of this order of echinoids from Paleogene deposits in the western half of the continent. Neolampadoid echinoids have been recorded, though not described, from the Neogene of the Eucla Basin. Specimens of Notolampas have been collected from the eastern part of the Eucla Basin, where they are said to occur in the Early
Miocene Abrakurrie Limestone (Holmes 1995). There is also an unsubstantiated record of a specimen referred to as Pisolampas sp. nov. by Philip (1970) occurring in this same formation (Holmes 1995).

The Late Eocene Pallinup Formation, within which the neolampadoid occurs, outcrops in the western part of the Eucla Basin (formerly the Bremer Basin) (Clarke et al. 2003). It is a unit of spongolite and siltstone that contains a small, but distinctive, echinoid fauna. The unit has been correlated with planktonic foraminiferal zone P15 (Late Eocene), and represents part of the Tuketja Transgression across southern Australia (Clarke et al. 2003). The Pallinup Formation forms part of the Plantagenet Group, and overlies the Late Eocene Werillup Formation. This formation, deposited within the Tortachilla Transgression, overlies the late Middle Eocene Nanarup Limestone, which also contains a distinctive echinoid fauna (Martin \& McNamara in prep.).

Few echinoids have been recorded from the Pallinup Formation. However, McNamara (1985) has described the spatangoid Linthia pulchra; and McNamara et al. (1986) recorded the spatangoid Gillechinus cudmorei Fell, 1964. Unlike other echinoid faunas from the Eucla Basin, the Pallinup Formation echinoids are invariably preserved as internal and external moulds. The specimen under consideration is, to our knowledge, unique for this formation in that it occurs as a chalcedonic internal mould. While external plate details are missing, the plate boundaries are exceptionally well preserved (Fig. 


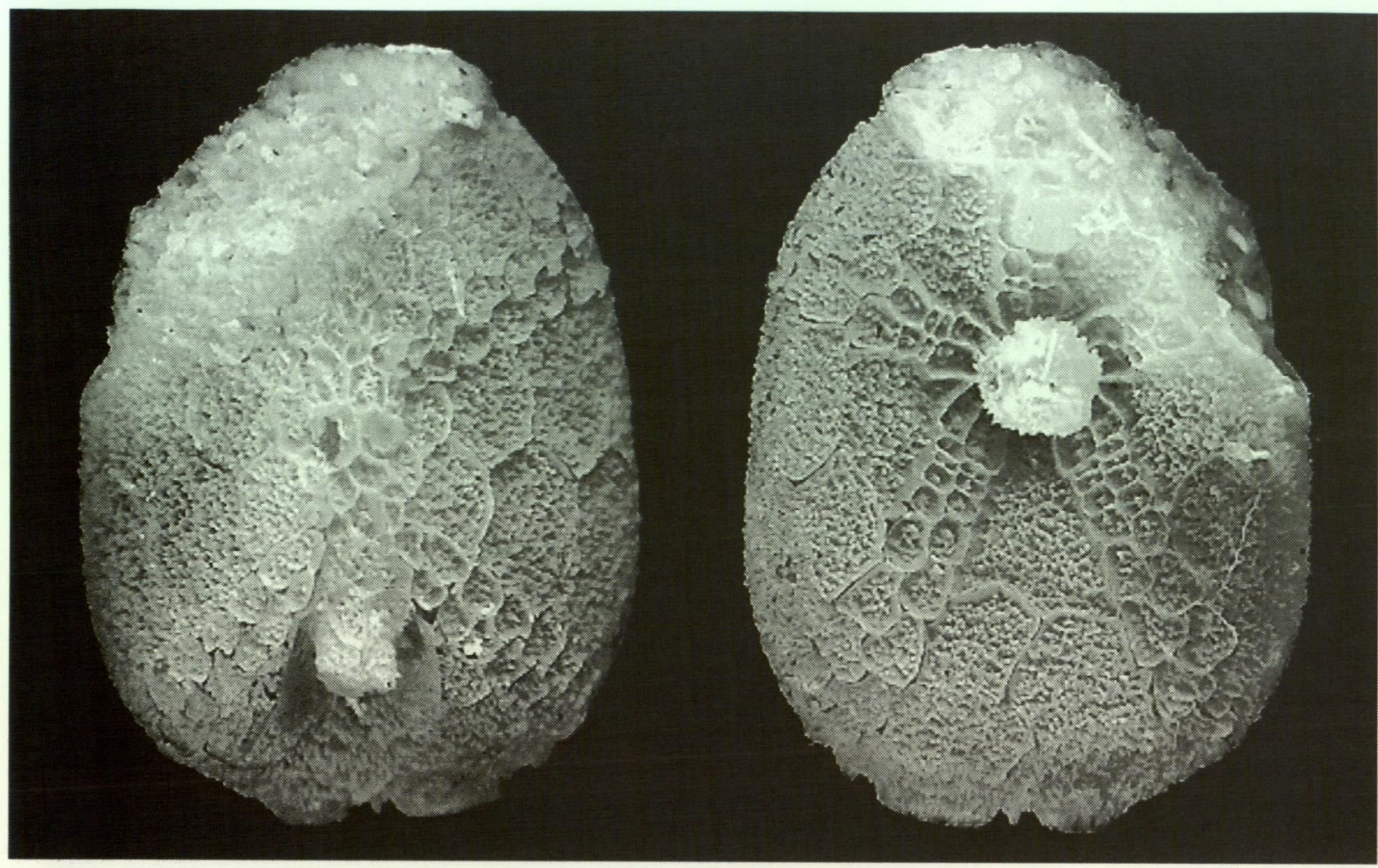

A

Figure 1 Aphanophora? cf. bassoris Holmes, 1995, WAM 65.7, Pallinup Formation, Lort River, Western Australia; A, adapical view; B, adoral view; both x11.5.

1). Gonopores are also preserved by being infilled with single crystals of quartz, the ' $c$ ' axes of which are perpendicular to the plane of the test.

The echinoid fauna of the Pallinup Formation is dominated by spatangoids, including Linthia pulchra McNamara, 1985, Gillechinus cudmorei Fell, 1964, ?Hemiaster sp., Schizaster cf. tatei McNamara and Philip 1980, Prenaster cf. aldingensis Hall 1907 and ?Pericosmus sp. The cidaroid ?Stereocidaris is also present.

Test parameters are expressed as \% TL, which refers to a measurement as a percentage of test length. Other measurements are in millimetres, measured under an optical microscope with calibrated graticule.

\section{SYSTEMATIC PALAEONTOLOGY}

\section{Order Neolampadoida Philip, 1963}

Suborder Neolampadina Philip, 1963

Family Neolampadidae Lambert, 1918

Genus Aphanophora? de Meijere, 1903

Aphanophora? cf. bassoris Holmes, 1995

Figures 1-3

\section{Material}

One siliceous internal mould, WAM 65.7, from "the Plantagenet Group". The specimen is recorded as having been collected from "Lort River", west of Esperance, Western Australia. Other material held in the collections of the Western Australian Museum from the Lort River region was collected from close to where the river intersects the AlbanyEsperance Road, suggesting the echinoid may be from the same vicinity. The other fossils collected from the Lort River area are molluscs, sponges and nautiloids and are characteristic of the Pallinup Formation. Moreover, there is no Werillup Formation preserved in the Lort River region (Thom et al. 1977), supporting the view that the test was derived from the Pallinup Formation. The nature of preservation, as an internal siliceous mould, rather than the original test, is also suggestive of derivation from this unit. Overall, the specimen is well preserved, with the exception of an incomplete anterior.

\section{Description}

Test elongate, elliptical, $8.2 \mathrm{~mm}$ long, tapering slightly towards posterior. Maximum width $75 \% \mathrm{TL}$, occurring 59\% TL from anterior. Test low, maximum height of $50 \%$ TL at around mid-test. Ventral surface 


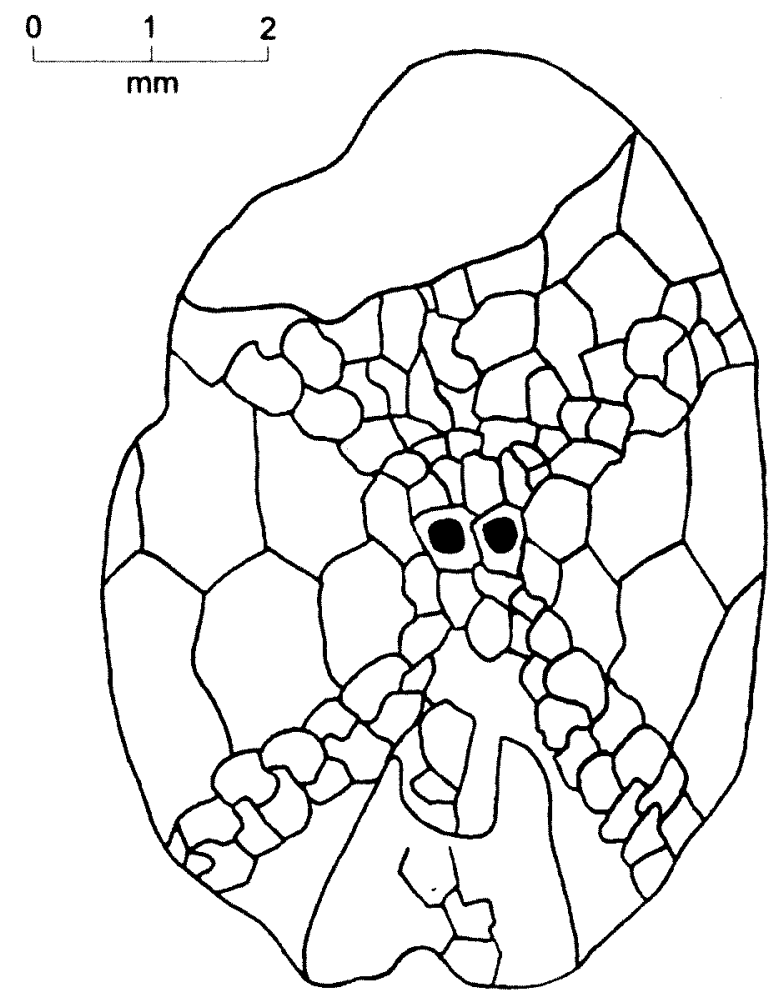

Figure 2 Adapical plating of Aphanophora? of. bassoris Holmes, 1995, WAM 65.7, Pallinup Formation, Lort River, Western Australia Anterior section not preserved.

concave around peristome. In lateral profile region between apex and posterior margin is steeper and flatter than gently curved area anterior of apical system. Ambitus rounded, with exception of a slight indentation on the posterior margin caused by anal groove. No anterior notch (Figures 1,2).

Apical system anterior of apex, and $49 \% \mathrm{TL}$ from test anterior; tetrabasal, with two gonopores (Figures 2,3); these occur in genital plates 1 and 4 and are large (diameter $=6 \% \mathrm{TL}$ ) and closely spaced. No hydropores preserved. Pore pairs not apparent. Anterior ambulacra diverge at $110^{\circ}$; posterior ambulacra at $75^{\circ}$. No demiplates visible adapically, although ambulacral plates appear to become more irregular in shape adambitally.

Periproct lies on adapical surface within an anal groove and on an angle of around $45^{\circ}$ to ventral surface. Anal groove relatively wide; length about $25 \%$ TL. Periproct rounded, longer than wide and inset well into the adapical surface. Periproct length $15 \% \mathrm{TL}$, width $10 \% \mathrm{TL}$. Anterior anal groove edge lies $73 \% \mathrm{TL}$ from anterior.

Peristome a little sunken within adoral surface; rounded, and slightly wider than long (Figure 1B). Peristome dimensions difficult to determine. Anterior margin lies $38 \% \mathrm{TL}$ from anterior ambitus; surrounded by small bourrelets; phyllodes biserial with regular rows of single pores. No demiplates visible within phyllodes; no buccal pores observed. Primary tubercles not preserved.

\section{Remarks}

Despite the absence of the test, the nature of the preservation of this specimen as an internal mould is such that the salient features required for its likely generic assignment are mainly preserved. These include, particularly, the tetrabasal apical system; presence of only two gonopores; adapical periproct situated in anal groove; and apparent absence of pore pairs in the adapical ambulacra. During his study of the Cenozoic species of neolampadoids from southern Australia, Holmes (1995) argued that a form from the Late Eocene Kingscote Limestone was distinct from the other three species in possessing a tetrabasal, rather than a monobasal, apical system and only two gonopores, both characteristics of the Pallinup Formation specimen. Pisolampas and Notolampas have three gonopores and Actapericulum four. Rather than assigning the Kingscote Limestone form to a new genus, Holmes questioningly assigned it as a new species within the living genus Aphanophora. The author of the genus, de Meijere (1903) did not provide a separate generic diagnosis in the original description, although he did in a subsequent paper (de Meijere 1904). This, as Holmes (1995) points out, shows a close concordance of characters between the Kingscote Island specimen and the modern form. However, neither de Meijere nor Mortensen (1948) provided any information on the nature of apical system. For this reason Holmes only questioningly assigned his form to the new taxon Aphanophora bassoris.

The Pallinup Formation specimen is very similar to the Kingscote Limestone species in most features.

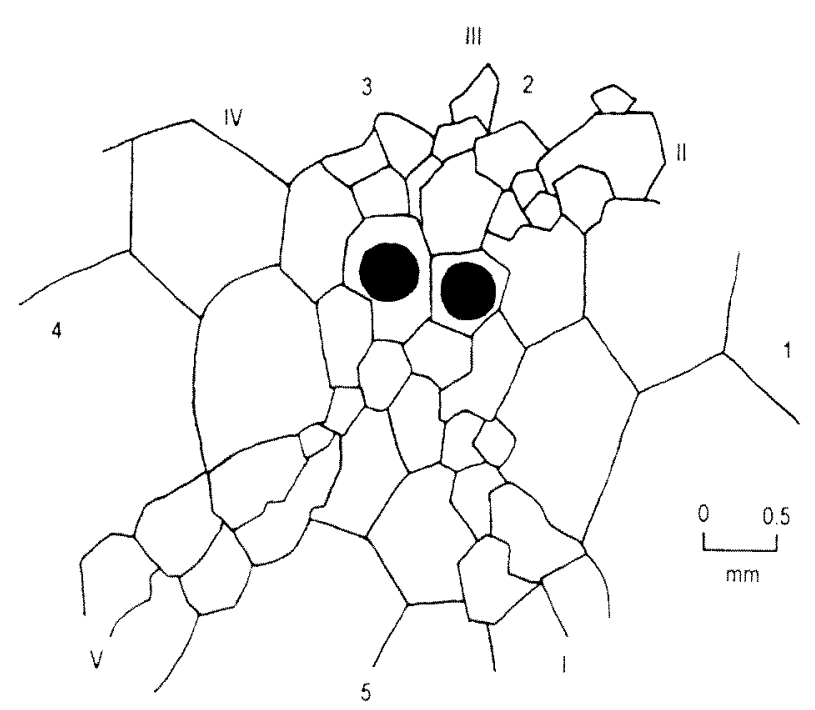

Figure 3 Plating of apical region of Aphanophora? cf. bassoris Holmes, 1995, WAM 65.7, Pallinup Formation, Lort River, Westem Australia. 
Table 1 Comparison of Aphanophora? cf. bassoris Holmes, 1995 from the Pallinup Formation with $A$.? bassoris from the Kingscote Limestone. TL=test length; TW=test width; $\mathrm{TH}=$ test height; Ant. $\mathrm{amb}=$ anterior ambulacrum; $\mathrm{PS}=$ peristome; $\mathrm{PP}=$ periproct; $P P L=$ periproct length; $P P W=$ periproct width.

\begin{tabular}{|c|c|c|}
\hline & $\begin{array}{l}\text { Pallinup } \\
\text { Fm }\end{array}$ & $\begin{array}{l}\text { Kingscote } \\
\text { Limestone* }\end{array}$ \\
\hline TL $(\mathrm{mm})$ & 8.2 & $7.5-11.0$ \\
\hline Max TW\%TL & 75 & $86.9-93.4$ \\
\hline TW from ant. \%TL & 59 & $52.4-63.2$ \\
\hline Max TH $\% \mathrm{TL}$ & 50 & $47.6-59.3$ \\
\hline TH from ant. $\% \mathrm{TL}$ & 50 & $49.5-63.6$ \\
\hline No. of gonopores & 2, large & 2, large or small \\
\hline Apical from ant. $\% T L$ & 49 & $43.7-53.5$ \\
\hline Adapical ant. amb ${ }^{\circ}$ & 110 & 127 \\
\hline Adapical post. amb ${ }^{\circ}$ & 75 & 76 \\
\hline PS from ant. \%TL & 38 & $37.8-43.1$ \\
\hline PPL \%TL & 15 & - \\
\hline PPW \%TL & 10 & $4.9-13.6$ \\
\hline PP from ant. \% TL & 73 & $66.0-77.8$ \\
\hline Posterior test angle ${ }^{\circ}$ & 45 & 46 \\
\hline
\end{tabular}

*Data from Holmes (1995) and Holmes (pers. com. 2004)

These include test length, test height, gonopore number, position of apical system, divergence of posterior adapical ambulacra, position of peristome, periproct width and angle of test surface close to periproct (see Table 1). The only significant differences between the two forms are the test width and angle of divergence of the anterior petals. The Pallinup Formation form has an appreciably narrower test (75\% TL vs $86.9-93.4 \% \mathrm{TL})$ and less divergent anterior petals $\left(110^{\circ}\right.$ vs $\left.127^{\circ}\right)$. Although there is probably a slight difference in ages between the Kingscote Limestone, which was deposited during the older Tortachilla Transgression, and the Pallinup Formation, which was deposited during the younger Tuketja Transgression, these two morphological differences are unlikely to be of sufficient significance to warrant the erection of new species.

\section{DISCUSSION}

A single specimen of a neolampadoid is known from the waters off the Western Australian coast. The $13.5 \mathrm{~mm}$ long, $10.8 \mathrm{~mm}$ wide specimen (WAM 97.1037) was dredged off the northwestern Australian coast at a depth of $324 \mathrm{~m}$ from moderately sorted, muddy sand at $23^{\circ} 18.18^{\prime} \mathrm{S}, 113^{\circ}$ 08.65'E. McNamara (1998) suggested that this specimen may be referred to Aphanophora.

A.? cf. bassoris from the Pallinup Formation differs from WAM 97.1037 in being relatively narrower (75\% TL compared with $80 \% \mathrm{TL}$ ) and having a less rounded posterior margin. However, both share some of the characteristic features of Aphanophora, notably the absence of pore pairs in the adapical ambulacra and supramarginal periproct. In both specimens weak bourelets are developed around the peristome. Unfortunately, the apical system of the living form is missing, thus it cannot be assigned to Aphanophora with certainty either.

It is interesting to note that, apart from $A . ?$ cf. bassoris from the Pallinup Formation, all the other neolampadoids from the Cenozoic of southern Australia occur exclusively in calcarenites (Holmes 1995). Although occurring in a much finer grained unit, the silty spongolites of the Pallinup Siltstone are considered to have been deposited in relatively shallow water, close to the shore line (Gammon et al. 2000). Today Aphanophora occurs in depths of 350-390m (McNamara 1998), suggesting that during the Cenozoic this neolampadoid has migrated from a relatively shallow, nearshore habitat, to a deeper, outer shelf environment.

\section{ACKNOWLEDGEMENTS}

We wish to thank Frank Holmes for his illuminating and constructive criticisms of an earlier draft of this paper, and Darren Mok for the photographs of the specimen.

\section{REFERENCES}

Clarke, J.A, Gammon, P.R., Hou, B. and Gallagher, S.J (2003). Middle to Upper Eocene stratigraphic nomenclature and deposition in the Eucla Basin. Australian Journal of Earth Sciences 50: 231-248.

Fell, H.B. (1964). New genera of Tertiary echinoids from Victoria, Australia. Memoirs of the National Musenm, Victoria 26: 211-217.

Gammon, P.R., James, N.P. and Pisera, A. (2000). Eocene spiculates and spongolites in southwestern Australia: Not deep, not polar, but shallow and warm. Geology 28: 855-858.

Hall, T.S. (1907). Four new echinoids from the Australian Tertiary. Proceedings of the Royal Society of Victoria 19: 47-53.

Holmes, F.C. (1995). Australian Tertiary Neolampadidae (Echinoidea): a review and description of two new species. Proceedings of the Royal Society of Victoria 107 : 113-127.

Lambert, J. (1918). Considérations sur la classification des Echinides Atélostomes. 1. Brachygnata et Procassiduloida. Mémoires Société Academique, d'agriculture, des sciences, arts et belles lettres $d u$ department de l'Aube 82: 1-48.

McNamara, K.J. (1985). The spatangoid echinoid Linthia from the Late Eocene of southern Australia. Transactions of the Royal Society of South Australia 109: 161-165.

McNamara, K.J. and Philip, G.M. (1980). Australian Tertiary schizasterid echinoids. Alcheringa 4: 47-65.

McNamara, K.J., Philip, G.M., and Kruse, P.D. (1986). 
Tertiary brissid echinoids of southern Australia. Alcheringa 10: 55-84.

McNamara, K.J. (1998). First records of holasteroid, neolampadoid and aeropsid echinoids from Australian waters. In R.Mooi and M. Telford Echinoderms: San Francisco, 734, Balkema, Rotterdam.

Meijere, J.C.H. de (1903). Vorläufige Beschreibung der neuen, durch die Siboga-Expedition gesammelten Echiniden. Tijdschrift der Nedelandsche Dierkundige Vereniging. ser.2, 8: 1-16.

Meijere, J.C.H. de (1904). Die Echinoidea der SibogaExpedition. Siboga-Expeditie (Uitkomsten op Zoologisch, Botanisch, Oceanographisch en Geologisch Gebied verzameld in de Oost-Indische Archipel 1899-1900 aan board H.M. Siboga ...), 43, M. Weber \& L.F. de Beaufort, eds, E.J. Brill, Leiden, 252 pp.
Mortensen, T. (1948), A monograph of the Echinoidea 4(1). Holectypoida, Cassiduloida. C. A. Rietzel, Copenhagen, $371 \mathrm{pp}$.

Philip, G.M. (1963). Two Australian Tertiary neolampadids, and the classification of cassiduloid echinoids. Palaeontology 6: 718-726.

Philip, G.M. (1970). Appendix 1 - Tertiary echinoids from the Eucla Basin. In Geology of the Western Australian part of the Eucla Basin. Bulletin of the Geological Survey of Western Australia 122: 182-191.

Thom, R., Lipple, S.L. and Sanders, C.C. (1977). Ravensthorpe: 1:250,000 Geological Series Explanatory Notes, Geological Survey of Western Australia, Perth.

Manuscript received 12 November 2003; accepted 22 January 2004 